\title{
BI Liaison Update
}

One of the most effective ways that academic librarians can promote the library's vital potential for improving quality teaching is by publishing articles in the professional journals that teaching faculty and administrators read.

The Bibliographic Instruction Liaison Project has compiled short lists of suggested readings in nine subject areas, and also distributes a general bibliography of appropriate articles selected to illustrate how academic libraries are currently participating in the educational process.

The general bibliography includes:

David Y. Allen, "Students need help in learning how to use the library," Chronicle of Higher Education, June 9, 1982, p.56.

Evan Ira Farber, "The Importance of Teaching Use of the Library," Library Issues: Briefings for Faculty and Administrators 2 (November 1981):3.

Evan Ira Farber, "Teaching the Use of the Library: Part II, Implementation," Library Issues: Briefings for Faculty and Administrators 2 (January 1982):3-4.

Alan E. Guskin, Carla J. Stoffle \& Joseph A. Boissé, "The Academic Library as a Teaching Library: A Role for the 1980's," Library Trends 28 (Fall 1979):281-96.

Nancy E. Gwinn, "The Faculty-Library Connection," Change 10 (September 1978):19-21.

Penelope S. Jeffrey, "Needed: The Teacher-
Librarian Team," English Journal 71 (September 1982):50-52.

Beverly Lynch \& Karen S. Seibert, "The Involvement of the Librarian in the Total Educational Process," Library Trends 29 (Summer 1980): 127-38.

Stacy E. Palmer, "Teaching students to do research: Professors get help from librarians," Chronicle of Higher Education, May 18, 1983, pp.27-28.

Carla J. Stoffle, “The Library's Role in Facilitating Quality Teaching," New Directions for Teaching and Learning 5 (1981):67-78.

Academic librarians who are interested in working more closely with teaching faculty and in devising library skills units that could be integrated into courses are encouraged to look over these articles and photocopy them for distribution to receptive faculty members and university administrators.

Copies of the readings lists in subject areas (languages and literature, history, sociology, psychology, fine arts, business, political science, education and the sciences) can be obtained by writing to me in care of LOEX, Eastern Michigan University Library, Ypsilanti, MI 48197. Please also contact me if you are publishing an article that could be included on the above list, or if you find a suitable article while scanning professional literature of higher education.-Carolyn Kirkendall.



